\title{
FUNCTIONAL AND STRUCTURAL RELATIONSHIPS IN THE GRAAFIAN FOLLICLE POPULATION OF THE SHEEP OVARY
}

\author{
MARY F. HAY AND R. M. MOOR \\ Agricultural Research Council Unit of Reproductive Physiology and Biochemistry, \\ University of Cambridge*
}

INTRODUCTION

The Graafian follicle population in sheep can be divided into two groups on the basis of the capacity that individual follicles have for secreting oestrogen when isolated from the remainder of the ovary (Moor, 1973). The most developed one or two non-atretic follicles from each animal generally produce large amounts of oestrogen in culture and can thus be classified as steroidogenically 'activated'. The other follicles usually produce very little oestrogen in culture and are accordingly classified as 'non-activated'

In this paper the above classification will be used and the two groups of follicles will be considered separately. In the first section of the paper the response of the non-activated follicles to gonadotrophic stimuli will be described and related to growth and atresia within this population. The steroidogenic potential of the activated follicles at different stages of the cycle will be discussed in the second part of the paper. In the third part, an attempt will be made to relate the ultrastructure of the activated follicles to the functional activity of their component tissues, namely the theca interna and membrana granulosa.

\section{THE NON-ACTIVATED FOLLIGLE POPULATION}

None of the follicles obtained from sheep after Day 4 of the cycle, with the exception of the one or two activated follicles, produce oestrogen in culture at a rate exceeding $10-15 \mathrm{ng} / \mathrm{mg}$ tissue per $24 \mathrm{hr}$ (Moor, 1973). This observation is in accord with the finding that oestrogen secretion in vivo occurs only in the ovary containing the large activated follicle; the smaller follicles in the other ovary secrete very little oestrogen (Bjersing et al., 1972). Between ovulation (Day 1) and Day 4 of the cycle, however, oestrogen production by small follicles is totally different from that observed at any other time (R. M. Moor, unpublished observations): many of the smaller follicles explanted 2-4 days after oestrus are steroidogenically activated and secrete significant amounts of oestrogen in culture. These activated small follicles probably contribute substantially to the high levels of oestrogen found in the blood early in the cycle.

In order to study the responsiveness of the steroidogenically inactive follicle population to hormonal stimulation we have administered PMSG to sheep

\footnotetext{
* Postal address: Animal Research Station, 307 Huntingdon Road, Cambridge CB3 0JQ.
} 
between Days 4 and 14 of the cycle. At selected stages after treatment the follicles were removed from the ovaries and maintained in organ culture (Moor et al., 1973). After an exposure to PMSG in vivo for only 5 min about $25 \%$ of small follicles over $2 \mathrm{~mm}$ in diameter acquired the capacity to produce significant amounts of oestrogen in vitro. Extension of the interval from $5 \mathrm{~min}$ to $12 \mathrm{hr}$ failed to increase the proportion of follicles stimulated to more than about $30 \%$, and did not raise the mean output of oestrogen per unit weight of follicular tissue. When the time of the exposure was lengthened to $24 \mathrm{hr}$, there was no increase in the mean number of follicles over $2 \mathrm{~mm}$ in diameter, but about $80 \%$ of them were stimulated and two to three times more oestrogen was produced in vitro per unit weight than by follicles exposed to the gonadotrophin for the shorter time interval.

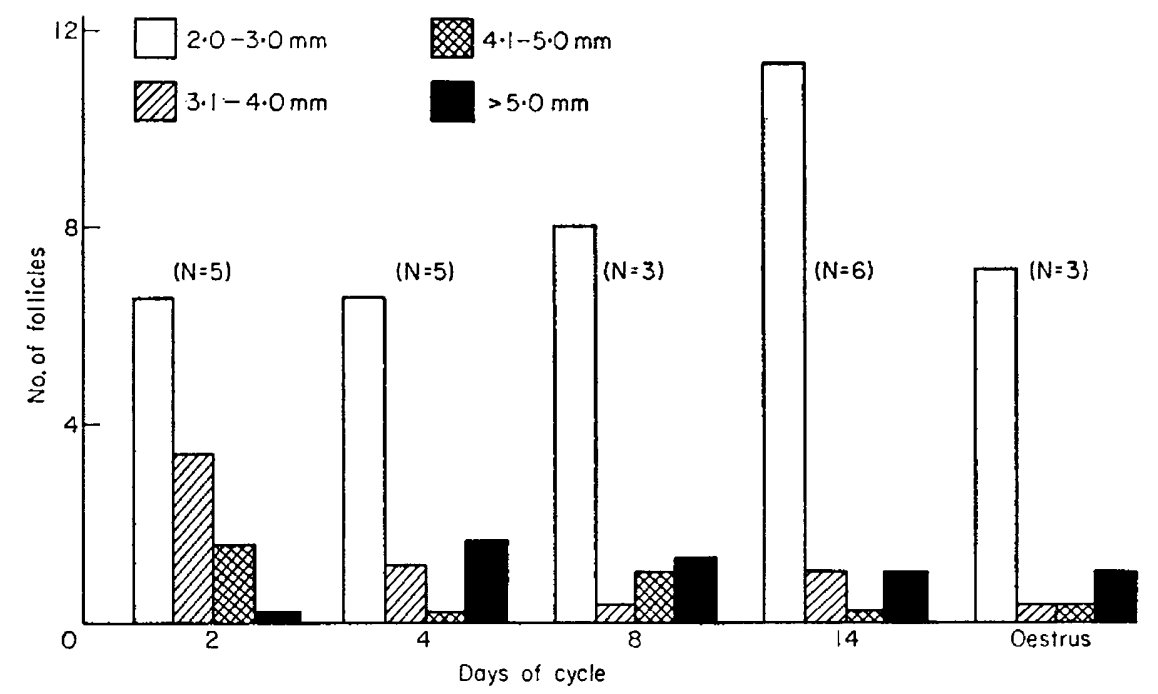

TEXT-FIG. 1. Histogram showing size distribution of Graafian follicles $\geqslant 2 \mathrm{~mm}$ in Welsh Mountain sheep during the oestrous cycle. $\mathbf{N}=$ number of sheep examined at each stage of cycle.

An explanation for the above results can perhaps be deduced from an examination of the pattern of growth and atresia of Graafian follicles in sheep. Follicle population changes have recently been studied by two groups of workers who between them have serially sectioned the ovaries of more than 50 Texel or Merino ewes and examined all follicles over $0.5 \mathrm{~mm}$ diameter (Brand \& de Jong, 1973; Turnbull \& Braden, 1975). From these studies and those of our own on Welsh Mountain ewes (Text-fig. 1), it is evident that within a particular breed the number and size distribution of follicles is constant throughout the oestrous cycle. According to Turnbull \& Braden (1975) about three to four follicles are freshly recruited into the growing population each day; growth once started continues until the follicle either becomes atretic or ovulates. Within each follicular size class, only about one-third of the follicles is normal, that is without signs of atresia; the remainder are in various stages of atresia. There 
thus appears to be an equilibrium between entry of follicles into a certain size class and their disappearance from it either by atresia or by passage into a higher size class.

It would appear probable that it is the $30 \%$ of non-atretic follicles that become activated after short exposure ( $5 \mathrm{~min}$ to $12 \mathrm{hr}$ ) to gonadotrophin in vivo (Moor et al., 1973). A large additional group of follicles becomes activated when the period during which the follicles are exposed to PMSG is extended to $24 \mathrm{hr}$. It is possible that at the time of injection of the PMSG, many of these more slowly activated follicles were already undergoing atresia. Under the influence of the gonadotrophin atresia appears to be arrested and furthermore to be reversible; the granulosa cells themselves may be capable of phagocytosing degenerating cellular elements including atretic bodies. PMSG may also prevent the small follicles from becoming atretic (Turnbull \& Braden, 1975), but this alone is unlikely to be the explanation for the greatly increased number of activated follicles found 18-24 hr after the injection of the gonadotrophin in our experiments. It is interesting that during the first 2-3 days of the cycle the ovaries are unable to respond to PMSG by showing an increase in the proportion of small follicles that subsequently secrete significant amounts of oestrogen (R. M. Moor, unpublished observations).

The effect of PMSG during the luteal phase of the cycle can be demonstrated histochemically. By $12 \mathrm{hr}$ after the injection of the gonadotrophin there is a small rise in the number of follicles showing $\Delta^{5}-3 \beta$-hydroxysteroid dehydrogenase ( $3 \beta$-HSD) activity in the theca interna as compared with untreated sheep; by $24 \mathrm{hr}$ this number is greatly increased and accompanied by a marked rise in oestrogen concentration in the ovarian vein blood (Hay \& Moor, 1975).

\section{STEROIDOGENIC POTENTIAL OF THE ACTIVATED FOLLIGLE POPULATION}

Oestrogen production by the ovary containing the large activated follicle varies in a clearly defined pattern during the oestrous cycle (Scaramuzzi et al., 1970; Cox et al., 1971). The output of oestrogen increases from low levels at ovulation to high levels about 3 days later. Thereafter oestrogen output declines to less than $50 \mathrm{ng} / \mathrm{hr}$ and apart from a transient increase around Day 8 does not rise again until 3 days before the ensuing ovulation. Oestrogen production by the sheep follicles is dominated by the secretion of oestradiol-17 $\beta$; oestrone accounts for only about $10 \%$ of the total oestrogen output (Moore et al., 1969). No detectable oestradiol- $17 \alpha$, oestriol or conjugated oestrogen is produced during the cycle in this species (Rado et al., 1970). The production of androgen by the ovaries of sheep parallels the production of oestrogen (Baird et al., 1968). Androstenedione and to a lesser extent testosterone levels increase sharply in the $72 \mathrm{hr}$ preceding ovulation, and after a transitory decline at ovulation increase again to high levels on Days 2 to 4 of the succeeding cycle.

Between Days 2 and 5, and from Day 13 up to oestrus, the activated follicles can be identified histochemically by the presence of $3 \beta$-HSD activity in the theca interna. The intensity of the reaction reaches a maximum during the 48 hr preceding ovulation (Hay \& Moor, 1973, 1975).

The pattern of steroids secreted by the activated follicles in culture parallels 
closely that observed in vivo; the one exception is that testosterone, and not its redox partner androstenedione, is the principal androgen secreted in vitro. The maternal environment has a dominant influence on the range and sequence of steroids produced by the large follicle in culture (Seamark et al., 1974; R. M. Moor, unpublished observations). During the first 4 days of the cycle oestrogen and androgen are the predominant steroids secreted by activated follicles in culture. It is important to reiterate that these two steroids appear in vivo in large amounts between the 2nd and 4th days after oestrus; also that at this stage of the cycle, both the large follicle and some of the smaller ones are contributing towards the total production of oestrogen. Large follicles explanted during the mid-luteal phase of the cycle (Day 8) secrete continuously high levels of oestrogen; no other steroids are secreted by follicles obtained at this stage. It is striking that despite the production of androgen and oestrogen, very little progestin is produced by follicles obtained from sheep between Days 2 and 14 of the cycle. This pattern of steroid production is reversed when follicles are explanted at oestrus; very little androgen or oestrogen is produced. Such follicles do not ovulate in vitro but they nevertheless undergo luteinization and secrete large amounts of progesterone, 20x-hydroxypregn-4-en-3-one and pregnenolone into the culture medium. The membrana granulosa of follicles that have luteinized in vitro exhibits $3 \beta$-HSD activity and in this resembles the granulosa lutein cells of the CL (Hay \& Moor, 1975). Several lines of evidence suggest that $\mathrm{C}_{18}$ and $\mathrm{C}_{19}$ steroids are secreted principally by the theca interna whereas $\mathrm{C}_{21}$ progestins are produced mainly by the membrana granulosa (Seamark et al., 1974).

Gyclical changes in the secretion of pituitary gonadotrophins offer an immediate explanation for some but not all of the differences in the range and pattern of steroids produced by activated follicles obtained at different stages of the cycle. It is evident that the basal secretion rate of FSH in sheep is relatively high (Text-fig. 2), although there are still wide variations in the reports of different workers with respect to the precise concentration of FSH in the peripheral blood (L'Hermite et al., 1972; Salamonsen et al., 1973). In spite of differences in absolute levels of production, certain similarities in the pattern of FSH secretion are apparent. A sharp increase in FSH levels at oestrus and again soon after ovulation occurs consistently in all experiments. The lowest concentrations of FSH were recorded immediately before and after the oestrous peak. Throughout the remainder of the cycle the levels fluctuate but are always very much above the $5-15 \mathrm{ng} / \mathrm{ml}$ basal secretion rate for LH (Geschwind \& Dewey, 1968; Pelletier et al., 1968; Wheatley \& Radford, 1969; Goding et al., 1969). A slight rise in the level of LH during the day preceding oestrus has been observed by Wheatley \& Radford (1969), but it is not until soon after oestrus that the level starts to rise sharply. Peak levels of LH $(100-200 \mathrm{ng} / \mathrm{ml}$ based on NIH-LH-S1 standard) occur about $6 \mathrm{hr}$ after the initiation of the LH surge and within a further 5-6 hr have again fallen to basal values (see Text-fig. 2).

The high levels of gonadotrophin secreted at oestrus exert a dominant effect on the steroidogenic potential of the follicles. Oestrogen secretion from the large preovulatory follicle is terminated by the high levels of $\mathrm{LH}$, and the follicle 


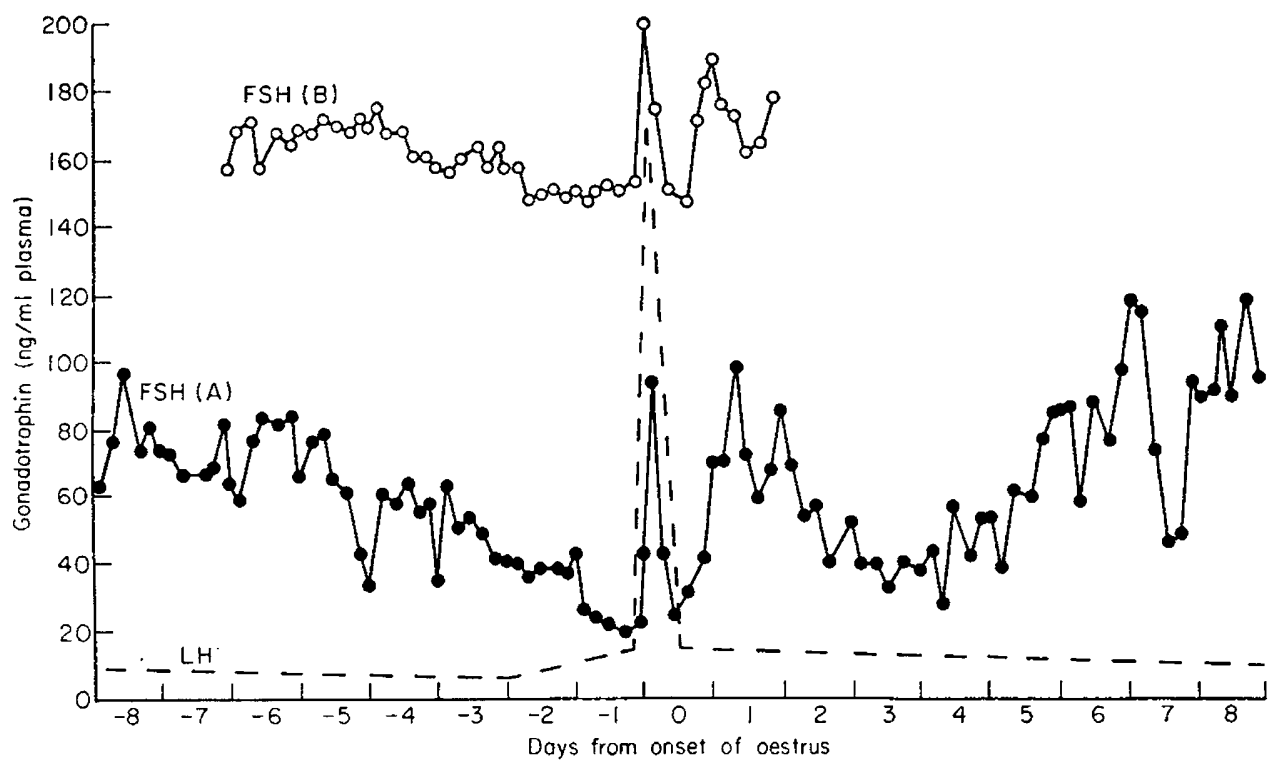

TEXT-FIG. 2. Concentration of FSH in terms of NIH-FSH-S1 standard (-) and LH in terms of NIH-LH-SI standard (- _ - - ) in the peripheral blood of the ewe during the oestrous cycle. For FSH, Curve $A$ has been constructed from the data of Salamonsen et al. (1973) obtained by bleeding individual sheep at $2 \mathrm{hr}$ intervals over periods of 4 days; in Curve B the data of L'Hermite et al. (1972) obtained by bleeding eight sheep at $4 \mathrm{hr}$ intervals for 10 days is presented in its original form. The $\mathrm{LH}$ curve is based on the data of Pelletier et al. (1968), Goding et al. (1969) and Wheatley \& Radford (1969).

finally becomes transformed into a secretor of progesterone and $20 \alpha$-dihydropregn-4-en-3-one (Moor, 1974). Our data would suggest that many of the smaller follicles are also influenced by the gonadotrophins present at oestrus (Seamark et al., 1974; R. M. Moor, unpublished observations), the result of this stimulation being reflected in the high output of androgen and $17 \alpha$-hydroxylated progestin by these follicles during the first 2-4 days of the ensuing cycle. By contrast, the marked increase in oestrogen secretion by follicles in the early follicular phase of the cycle is not preceded or accompanied by any large change in gonadotrophin secretion.

\section{ULTRASTRUGTURE OF ACTIVATED FOLLIGLES}

Although the theca interna is the main source of ovarian oestrogen production in the sheep (Seamark et al., 1974), this tissue is rather poorly differentiated throughout most of the oestrous cycle. It consists mainly of elongated fibroblastlike cells interspersed with a few larger epithelioid-type cells; collagen fibrils are numerous. On Day 15, however, when the preovulatory production of oestrogen reaches its peak, the theca interna of the largest follicle becomes more highly vascularized and there is a concomitant increase in the number and size of the large epithelioid cells (Bjersing et al., 1972). With the electron microscope it can be seen that these cells have many ultrastructural characteristics that are typical of steroid-secreting cells (Ghristensen \& Gillim, 1969). They contain 
moderate amounts of smooth endoplasmic reticulum (SER), some profiles of rough endoplasmic reticulum (RER), a well developed Golgi apparatus, and elongated mitochondria, in some of which the cristae are tubular. Unlike many steroid-secreting cells, the thecal cells of follicles that are secreting oestrogen contain very few lipid droplets and virtually no membrane-bound dense granules; the scarcity of these intracellular inclusions may be related to a high turnover rate of steroid with little storage of precursors or product. The theca externa contains fibroblasts and also myoid cells which resemble smooth muscle cells and may have a contractile function (O'Shea, 1973). There is no sharp boundary between the theca interna and externa or between the latter and the stromal tissue of the ovary.

In contrast to the theca interna, the membrana granulosa has a well-defined ultrastructural organization which has been studied in many species. The functional activity of the granulosa is, however, much less clear than that of the theca. At the time when the preovulatory follicle is actively secreting oestrogen, the granulosa cells have no direct blood supply and appear to be steroidogenically inactive (Seamark et al., 1974). They do, however, synthesize and secrete substances such as mucopolysaccharides (Odeblad \& Boström, 1953; Zachariae, 1957) and proteins (Björkman, 1962; Priedkalns \& Weber, 1968 ) into the follicular fluid. This fluid is basically a transudate of plasma; its components and function have recently been reviewed by Edwards (1974). The membrana granulosa may influence the composition of follicular fluid by acting as a blood-follicle barrier, thereby preventing certain substances, e.g. proteins of high molecular weight, from entering the follicular fluid (Shalgi et al., 1973; Zamboni, 1974).

In the oestrogen-secreting Graafian follicle the membrana granulosa has the appearance of a stratified epithelium composed of 5-15 layers of cells and is sharply separated from the theca interna by a distinct basal lamina ( $\mathrm{Pl}$. 1, Fig. 1). The basal granulosa cells are columnar and closely apposed, while those nearer the antrum are more rounded with pools of follicular fluid between them. In the electron microscope it is evident that the cells in the basal region of the membrana granulosa have a very compact arrangement (Pl. 1, Fig. 1). Processes of the granulosa cells appear to invaginate into neighbouring cells, probably resulting in a complex cellular network. The intercellular space is about $200 \AA$ wide but it is interrupted by junctional complexes which connect adjacent cells (Pl. 2, Fig. 2). These complexes have two main forms: (1) the abutment form, a specialized area of the plasmalemma which often extends over a considerable distance and the junctional area may involve the plasmalemma of the body of the cell, or alternatively of a cell process which is invaginating into another granulosa cell; (2) the annular form in which the junctional complex appears to be completely separate from the plasmalemma of the cell. Some of the annular complexes are probably transverse sections of finger-like cell processes which have invaded neighbouring cells, while others may be true intracellular inclusions, derived from a pinching-off of part of an invading process (Merk et al., 1973). Similar intercellular connections have been observed in the membrana granulosa of mature follicles of virtually all species that have been examined in the electron microscope, including rhesus 


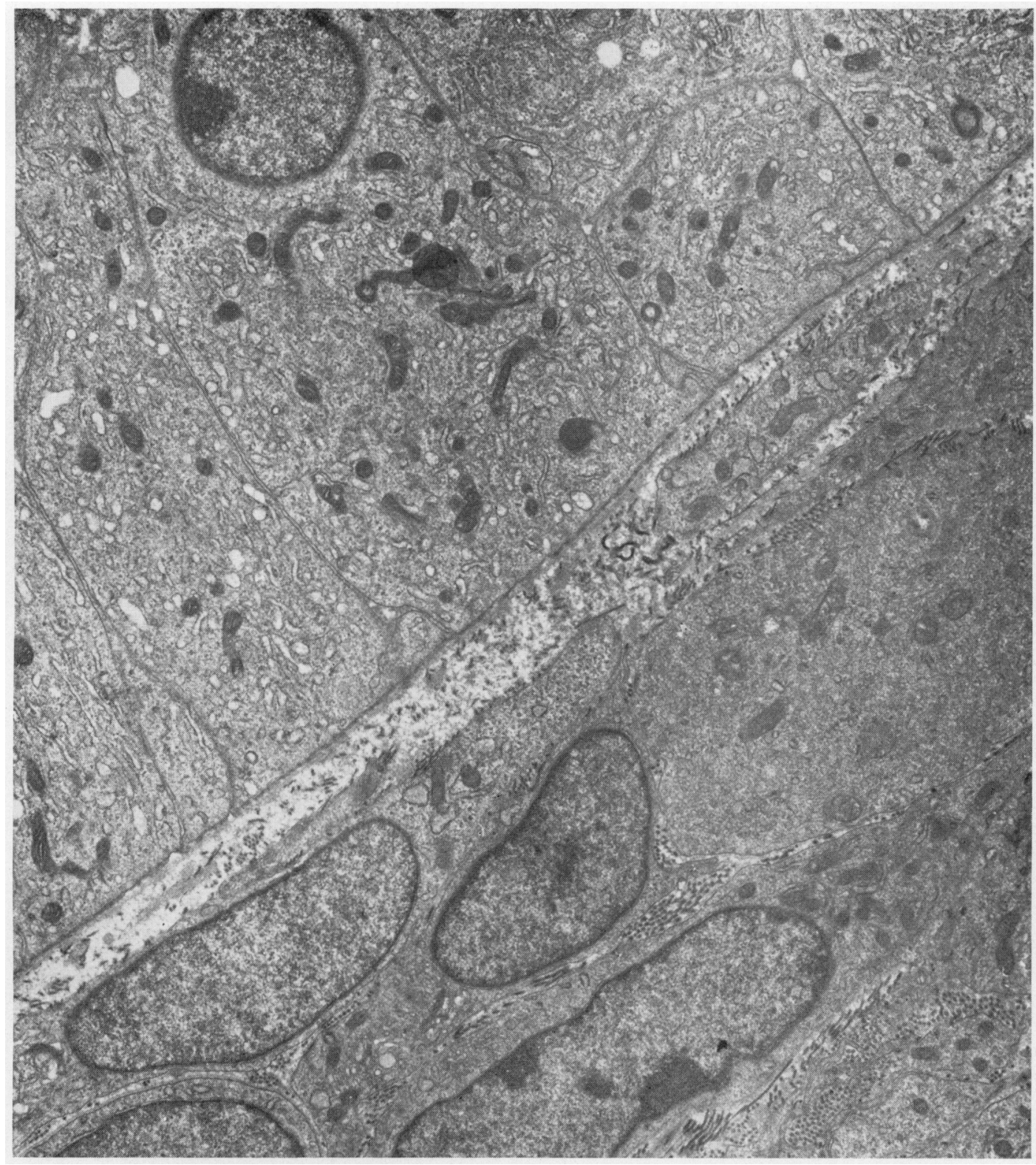

Figs. 1-4. Electron micrographs of steroidogenically activated ovarian follicles of shecp on Day 15 of the oestrous rycle.

FIG. 1. Closely packed columnar cells in the basal part of the membrana granulosa are shown in the upper left half of the figure; in the lower right half, the circumferentially arranged cells of the theca interna can be seen. The membrana granulosa rests on a distinct basal lamina. Numerous collagen fibrils are present in the theca interna. $\times 10.000$. 

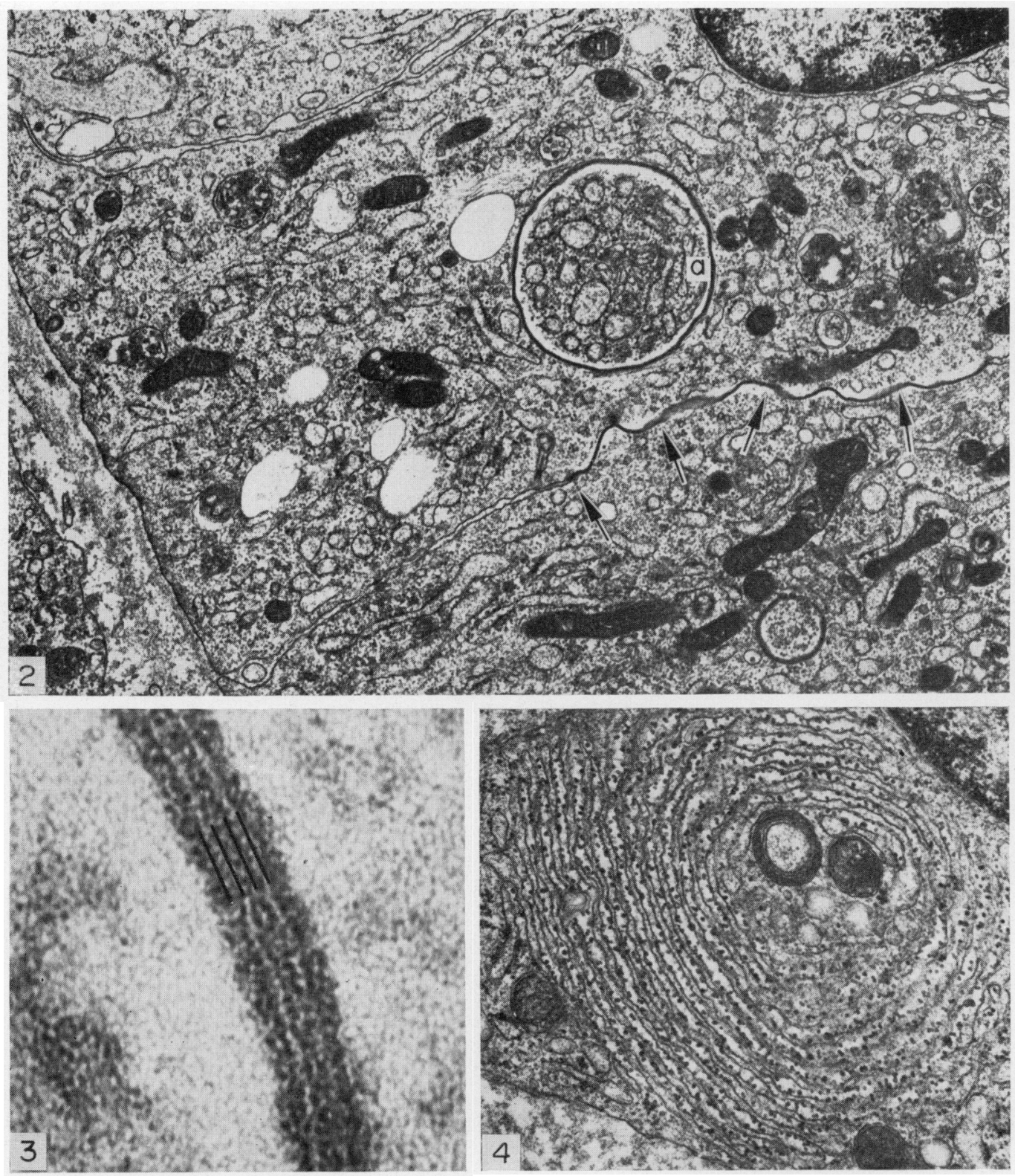

IFr. 2. Part of three basal granulosa cells showing abutment (arrows) and annular (a) junctional complexes. Profiles of rough endoplasmic reticulum and numerous free ribosomes and polyribosomes can also be seen. $\times 15.000$.

Fici. 3. Seven-layered gap junction. $\times 4.50 .000$.

Fur. 4. Cilycogen body. $\times 43,000$. 
monkey (Zamboni, 1974), cow (Priedkalns \& Weber, 1968), rabbit (Blanchette, 1966; Espey \& Stutts, 1972), rat (Björkman, 1962; Merk et al., 1972, 1973), mouse (Byskov, 1969; Anderson, 1971) and bat (Wimsatt \& Parks, 1966), but until recently very little attention has been paid to the structure or functional significance of these junctional complexes. When attempts have been made to discuss them in more detail (Espey \& Stutts, 1972; Merk et al., 1972, 1973; Zamboni, 1974), confusion over the terminology used to describe the junctions has tended to obscure interpretation of their function.

Tight junctions and gap junctions though structurally and functionally quite distinct (Pappas, 1973) are difficult to distinguish in electron micrographs unless special preparative methods are employed. The seven-layered gap junctions can be identified in tissue that has been block-stained with uranyl acetate (Karnovsky, 1967). A more critical identification can be obtained by the use of electron-dense tracer molecules such as lanthanum (Revel \& Karnovsky, 1967) which can enter the narrow $(20 \AA)$ intercellular space of a gap junction, but are excluded by the fused outer leaflets of the two apposing cell membranes of a tight junction. Gap junctions can also be identified in freeze-fracture preparations (Chalcroft \& Bullivant, 1970; McNutt \& Weinstein, 1970).

There is good evidence from freeze-fracture studies for the existence of gap junctions between granulosa cells in the rat (Fletcher \& Everett, 1973; Fletcher, 1973). We have also observed gap junctions in the membrana granulosa of sheep follicles that have been block-stained with uranyl acetate (Pl. 2, Fig. 3). It is probable that many of the junctional complexes variously described in the membrana granulosa of many species are in fact gap junctions. Such junctions would provide a means of intercellular communication and allow the granulosa cells to function in a unified manner. The membrana granulosa has been considered as a 'functional syncytium' (Merket al., 1972) through which chemical and hormonal stimuli may be propagated and metabolic exchange occur. Gap junctions may also play a role in the inhibitory influence that the membrana granulosa has on the maturation of the oocyte (Foote \& Thibault, 1969).

Tight junctions, on the other hand, have not been demonstrated convincingly in the membrana granulosa although pentalaminar junctional complexes have been observed by a number of workers including Zamboni (1974) and M. F. Hay \& R. M. Moor (unpublished). Such configurations may, however, be artifacts arising from adherence of the two central membranes of a gap junction; special methods, such as those used by Dym \& Fawcett (1970) and Dym (1973) in their elegant studies on the testis, are required to identify tight junctions with greater certainty. Zamboni (1974) has suggested that tight junctions may be involved in the formation of the blood-follicle barrier. He has postulated that this barrier may be as effective in maintaining a homeostatic environment around the oocyte as that provided for developing spermatozoa by the tight junctions that are present between the Sertoli cells and are responsible for the blood-testis barrier (Fawcett et al., 1970; Dym \& Fawcett, 1970). The 'tightness' of the barrier is clearly different in the two organs as very little serum protein is able to enter the seminiferous tubules (Tuck $e t$ al., 1970), whereas only proteins of high molecular weight are excluded by the blood-follicle barrier (Shalgi et al., 1973). The report of Lipner \& Cross (1968) 
that the membrana granulosa in the rabbit is a pseudostratified epithelium rather than a stratified one may be relevant to the structural basis of the blood-follicle barrier, if a morphological barrier exists.

The fine structure of the granulosa cells themselves is consistent with the view that they have considerable synthetic ability. The cells have a welldeveloped Golgi apparatus, and a moderate amount of endoplasmic reticulum, mainly of the granular variety but with rather few ribosomes attached to the membranes. There are, however, numerous free ribosomes and polyribosomes, a characteristic of rapidly proliferating cells and also of cells that are synthesizing protein but not secreting it (Birbeck \& Mercer, 1961). Granulosa cells contain virtually no membrane-bound granules and very few dense bodies; lipid droplets also are usually scarce but occasional cells contain large amounts of lipid.

One unusual structure frequently seen in ovine granulosa cells during the $48 \mathrm{hr}$ before ovulation are glycogen bodies, a spheroidal association of $\beta$ glycogen particles and SER (Pl. 2, Fig. 4); glycogen bodies are often located in the basal part of the cells, close to the basal lamina. Corteel (1973) also observed them in the granulosa cells of the sheep follicle around the time of oestrus, but reported that at earlier stages of the cycle glycogen is distributed round the periphery of vacuoles. In the rabbit Blanchette (1966) found that glycogen granules do not become apparent in the granulosa cells until shortly before ovulation, when they are dispersed throughout the cytoplasmic matrix. As far as we are aware, glycogen bodies have not been recorded in the granulosa cells of any species other than the sheep. Their significance is unknown but Corteel (1973) has suggested that they may be the source of the large amounts of SER which develop rapidly when granulosa cells luteinize at ovulation. Glycogen bodies have been reported in a number of other cell types (see Le Beux, 1969), usually at times when they were undergoing active differentiation or transformation; glycogen bodies are particularly prevalent in liver cells under certain pathological conditions, in hepatoma cells and in embryonic skeletal cells. Le Beux (1969) has described their structure in detail in the ciliated epithelial cells of the rabbit oviduct at oestrus, and considers that the glycogen bodies may be hormone-dependent and also related to the production of SER.

\section{GONGLUDING REMARKS}

The ovulating follicle enters the actively growing follicle population on Day 6 or 7 of the cycle in which it is destined to ovulate (Turnbull \& Braden, 1975). Between Days 6 and 12 it increases in diameter from $0.5 \mathrm{~mm}$ to $2.2 \mathrm{~mm}$, and by the onset of oestrus its diameter is about $5.0 \mathrm{~mm}$; during the final $18 \mathrm{hr}$ before ovulation there is a rapid increase in growth. In this paper we have been concerned mainly with the Graafian follicle population during the luteal and early follicular phases of the cycle when, amongst the $30 \%$ of follicles that show no sign of atresia, only one or two are steroidogenically activated. The activated follicle secretes steroids in a range and pattern predetermined by the maternal environment. However, the mechanism involved in the selection of follicles for 
activation is at present unknown. In this connection, it is of interest that about $30 \%$ of follicles over $2 \mathrm{~mm}$ in diameter, i.e. probably most of the non-atretic follicles in that size category, can be activated by a short ( $5 \mathrm{~min}$ to $12 \mathrm{hr}$ ) exposure in vivo to exogenous gonadotrophin. By contrast, when the length of exposure is increased to $18-24 \mathrm{hr}$, about $80 \%$ of the follicles respond to the gonadotrophin; in these circumstances it is likely that the atretic process is being arrested and even reversed.

Another important aspect of follicular function is that of providing a suitable environment for the developing oocyte. Follicular fluid is primarily a transudate of plasma, but the existence of a blood-follicle barrier which may exclude certain substances from the follicular fluid has been postulated over a number of years (Zachariae, 1958; Shalgi et al., 1973). As yet no adequate morphological concept of this barrier has been proposed, but it is possible that the extensive development of intercellular junctional complexes in the membrana granulosa may contribute towards the formation of such a barrier which perhaps functions as a molecular sieve.

Intercommunication between cells within the membrana granulosa and between granulosa cells and the oocyte is probably of importance both for the unified function of the granulosa cells and for normal maturation of the oocyte (Foote \& Thibault, 1969). The gap junctions within the membrana granulosa probably play a key role in both these processes. The integrity of the junctional complexes may be oestrogen-dependent (Merk et al., 1972), thus indicating a possible intrafollicular relationship between the steroidogenic function of the thecal cells and the maturation of the oocyte.

\section{REFERENCES}

ANDERson, E. (1971) Intercellular junctions in the differentiating Graafian follicle of the mouse. Anat. Rec. $169,473$.

Batrd, D.T., Goding, J.R., IchiKawA, Y. \& McCracken, J.A. (1968) The secretion of steroids from the autotransplanted ovary in the ewe spontaneously and in response to systemic gonadotrophin. 7. Endocr. 42, 283-299.

Birbeck, 'M.S.C. \& Mercer, E.H. (1961) Cytology of cells which synthesize protein. Nature, Lond. $189,558-560$.

Bjersing, L., Hay, M.F., Kann, G., Moor, R.M., Naftolin, F., Scaramuzzi, R.J., Short, R.V. \& YouNGLAI, E.V. (1972) Changes in gonadotrophins, ovarian steroids and follicular morphology in sheep at oestrus. F. Endocr. 52, 465-479.

BJörkman, N. (1962) A study of the ultrastructure of the granulosa cells of the rat ovary. Acta anat. 51, $125-147$.

Blanchetre, E.J. (1966) Ovarian steroid cells. I. Differentiation of the lutein cell from the granulosa follicle cell during the preovulatory stage and under the influence of exogenous gonadotrophins. 7. Cell Biol. 31, 501-516.

BRAND, A. \& DE JONG, W.H.R. (1973) Qualitative and quantitative micromorphological investigations of the tertiary follicle population during the oestrous cycle in sheep. F. Reprod. Fert. 33, 431-439.

Byskov, A.G.S. (1969) Ultrastructural studies on the pre-ovulatory follicle in the mouse ovary. $Z$. Zellforsch. mikrosk. Anat. 100, 285-299.

Chalcroft, J.P. \& Bullivant, S. (1970) An interpretation of liver cell membrane and junction structure based on observations of freeze-fracture replicas of both sides of fracture. 7 . Cell Biol. 47, $49-60$.

Christensen, A.K. \& Gilim, S.W. (1969) The correlation of fine structure and function in steroidsecreting cells with emphasis on those of the gonads. In The Gonads, Ch. 16, pp. 415-488. Ed. K. W. McKerns. North-Holland Publishing Company, Amsterdam.

Corteel, M. (1973) Etude histologique de la transformation du follicle preovulatoire en corps jaune 
cyclique chez la brebis. I. Evolution des ultrastructures des cellules de la granulosa. Annls Biol. anim. Biochim. Biophys. 13, 249-260.

Cox, R.I., Mattner, P.E. \& Thorburn, G.D. (1971) Changes in ovarian secretion of oestradiol-17 $\beta$ around oestrus in the sheep. F. Endocr. 49, 345-346.

Dym, M. (1973) The fine structure of the monkey (Macaca) Sertoli cell and its role in maintaining the blood-testis barrier. Anat. Rec. 175, 639-656.

DyM, M. \& FAwCETT, D.W. (1970) The blood-testis barrier in the rat and the physiological compartmentation of the seminiferous epithelium. Biol. Reprod. 3, 308-326.

EDWARDs, R.G. (1974) Follicular fluid. 7. Reprod. Fert. 37, 189-219.

Espey, L.L. \& STUTTs, R.H. (1972) Exchange of cytoplasm between cells of the membrane granulosa in rabbit ovarian follicles. Biol. Reprod. 6, 168-175.

Fawcetr, D.W., Leak, L.V. \& Heidger, P.M. (1970) Electron microscopic observations on the structural components of the blood-testis barrier. F. Reprod. Fert., Suppl. 10, 105-122.

FLETcher, W.H. (1973) Diversity of intercellular contacts in the rat ovary. F. Cell Biol. 59, 10la.

FLETCHER, W.H. \& EVERETT, J.W. (1973) Ultrastructural reorganization of rat granulosa cells on the day of proestrus. Anat. Rec. 175, 320 .

Foote, W.D. \& Thibault, C. (1969) Recherches expérimentales sur la maturation in vitro des ovocytes de truie et de veau. Annls Biol. anim. Biochim. Biophys. 9, 329-349.

Geschwind, I.I. \& Dewey, R. (1968) Dynamics of luteinizing hormone (LH) secretion in the cycling ewe: a radioimmunoassay study. Proc. Soc. exp. Biol. Med. 129, 451-455.

Goding, J.R., Catt, K.J., Brown, J.M., Kaltenbach, G.C., Cumming, I.A. \& Mole, B.J. (1969) Radioimmunoassay for ovine luteinizing hormone. Secretion of luteinizing hormone during estrus and following estrogen administration in the sheep. Endocrinology 85, 133-142.

HAY, M.F. \& MooR, R.M. (1973) The graafian follicle of the sheep: relationships between gonadotrophins, steroid production, morphology and oocyte maturation. Annls Biol. anim. Biochim. Biophys. 13, 241-248.

HAY, M.F. \& MoOR, R.M. (1975) Distribution of $\Delta^{5}-3 \beta$-hydroxysteroid dehydrogenase activity in the Graafian follicle of the sheep. F. Reprod. Fert. 43, 313-322.

KaRnovsky, J.J. (1967) The ultrastructural basis of capillary permeability studied with peroxidase as a tracer. F. Cell Biol. 35, 213-236.

LE BEUX, Y.J. (1969) An unusual ultrastructural association of smooth membranes and glycogen particles: the glycogen body. Z. Zellforsch. mikrosk. Anat. 101, 433-447.

L'Hermite, M., Niswender, G.D., Reichert, L.E., JR \& Midgley, A.R., JR (1972) Serum folliclestimulating hormone in sheep as measured by radioimmunoassay. Biol. Reprod. 6, 325-332.

LipNer, H. \& GROss, N.L. (1968) Morphology of the membrana granulosa of the ovarian follicle. Endocrinology 82, 638-641.

Merk, F.B., Botticelli, C.R. \& Albright, J.T. (1972) An intercellular response to estrogen by granulosa cells in the rat ovary; an electron microscope study. Endocrinology 90, 992-1007.

Merk, F.B., Albright, J.T. \& Botricelli, G.D. (1973) The fine structure of granulosa cell nexuses in rat ovarian follicles. Anat. Rec. 175, 107-126.

McNutt, N.S. \& Weinstein, R.S. (1970) The ultrastructure of the nexus. A correlated thin section and freeze-cleave study. F. Cell Biol. 47, 666-688.

MooR, R.M. (1973) Oestrogen production by individual follicles explanted from ovaries of sheep. J. Reprod. Fert. 32, 545-548.

Moor, R.M. (1974) The ovarian follicle of the sheep: inhibition of oestrogen secretion by luteinizing hormone. F. Endocr. 61, 455-463.

MooR, R.M., HAY, M.F., McINTosh, J.E.A. \& CALDWELx, B.V. (1973) Effect of gonadotrophins on the production of steroids by sheep ovarian follicles cultured in vitro. F. Endocr. 58, 599-611.

Moore, N.W., Barrett, S. Brown, J.B., Schindler, I., Smith, M.A. \& SmYth, B. (1969) Oestrogen and progesterone content of ovarian vein blood of the ewe during the oestrous cycle. $\mathcal{F}$. Endocr. 44, $55-62$.

ODEBLAD, E. \& BOSTRÖM, H. (1953) Time-picture relation study with autoradiography on uptake of labelled sulphate in graafian follicles of rabbit. Acta radiol. 39, 137-140.

O'SheA, J.D. (1973) The ultrastructure, origin and fate of the theca externa of ovarian follicles in the sheep. Res. vet. Sci. 14, 273-278.

PAPpas, G.D. (1973) Junctions between cells. Hospital Practice 8, 39-46.

Pelletier, J., Kann, G., Dolais, J. \& Rosselin, G. (1968) Dosage radio-immunologique de l'hormone lutéinisante plasmatique chez le mouton. Comparaison avec le dosage biologique de LH par la diminution de l'acide ascorbique ovarien, et exemple d'application aux mesures de la LH sanguine chez la brebis. C. r. hebd. Séanc. Acad. Sci., Paris 266, 2352-2354.

Priedralns, J. \& Weber, A.F. (1968) Ultrastructural studies of the bovine graafian follicle and corpus luteum. Z. Zellforsch. mikrosk. Anat. 91, 554-573. 
RADo, A., McGracken, J.A. \& BatRD, D.T. (1970) The formation of oestrogens by the autotransplanted ovary of the ewe perfused in vivo with $\mathrm{C}_{19}$ steroids. Acta endocr., Copenh. 65, 244-260.

Rever, J.P. \& Karnovsky, M.J. (1967) Hexagonal array of subunits in intercellular junctions of the mouse heart and liver. 7. Cell Biol. 33, C7-C12.

Salamonsen, L.A., Jonas, H.A., Burger, H.G., Bugkmaster, J.M., Chamley, W.A., Cumming, I.A., FINDLAY, J.K. \& GodING, J.R. (1973) A heterologous radioimmunoassay for follicle-stimulating hormone: application to measurement of FSH in the ovine oestrous cycle and in several other species including man. Endocrinology 93,610-618.

Scaramuzzi, R.J., CALdwell, B.V. \& Moor, R.M. (1970) Radioimmunoassay of LH and estrogen during the estrous cycle of the ewe. Biol. Reprod. 3, 110-119.

Seamark, R.F., Moor, R.M. \& McINTosh, J.E.A. (1974) Steroid hormone production by sheep ovarian follicles cultured in vitro. F. Reprod. Fert. 41, 143-158.

Shalgi, R., Kraicer, P., Rimon, A., Pinto, M. \& Sofrrman, N. (1973) Proteins of human follicular fluid: the blood-follicle barrier. Fert. Steril. 24, 429-434.

Tuck, R.R., Setchell, B.P., Wartes, G.M.H. \& Young, J.A. (1970) The composition of fluid collected by micropuncture and catheterization from the seminiferous tubules and rete testis of rats. Pflugers Arch. ges. Physiol. 318, 225-243.

Turnbull, K.E. \& Braden, A.W.H. (1975) The pattern of follicular growth and atresia in the ovine ovary. Aust. F. biol. Sci. (in press).

WHEATLEY, I.S. \& RADFORD, H.M. (1969) Luteinizing hormone secretion during the oestrous cycle of the ewe as determined by radio-immunoassay. F. Reprod. Fert. 19, 211-214.

Wimsatr, W.A. \& PARKs, H.F. (1966) Ultrastructure of the surviving follicle of hibernation and of the ovum-follicle cell relationship in the vespertilionid bat, Myotis lucifugus. Symp. zool. Soc. Lond. 15, 419-454.

ZachariaE, F. (1957) Studies on the mechanism of ovulation. Autoradiographic observations on the uptake of radioactive sulfate $\left({ }^{35} \mathrm{~S}\right)$ into the ovarian follicular mucopolysaccharides. Acta endocr., Copenh. 26, 215-224.

Zacharias, F. (1958) Studies on the mechanism of ovulation. Permeability of the blood-liquor barrier. Acta endoct., Copenh. 27, 339-342.

Zamboni, L. (1974) Fine morphology of the follicle wall and follicle cell-oocyte association. Biol. Reprod. 10, 125-149. 